\title{
The curious citation practices of Avner Greif: Janet Landa comes to grief
}

\author{
C.K. Rowley
}

Received: 6 April 2009 / Accepted: 7 April 2009 / Published online: 15 April 2009

(C) Springer Science+Business Media, LLC 2009

\begin{abstract}
This commentary demonstrates that Avner Greif, through his citation practices, has denied Janet Landa her full intellectual property rights with respect to her contributions to the economic analysis of trust and identity. He has done so by systematically failing to cite her published papers in this field, incidentally promoting his own publications as meriting priority. In consequence, he has effectively blocked out Janet Landa's work from the mainstream economics literature, albeit not from the literature of law and economics, where his own writings have not been directed.
\end{abstract}

Keywords Ethnically homogeneous middleman group · Maghribi traders' coalition · Economics of trust $\cdot$ Economics of identity $\cdot$ Priority citations

\section{Introduction}

For better or for worse, the analysis of citations plays a significant role in higher education. Pioneered in the United States during the 1950s, bibliometrics was invented as a tool for tracing research ideas, the progress of science and the impact of scientific work. The implicit assumption is that if an article is widely cited, it has a greater impact and also is of high quality. If a researcher has one widely cited paper, then he is considered influential. If he has many non-cited works, then he is seen as less influential. Universities and departments are ranked internationally, in part, on the basis of such citations. Naturally, therefore, they take citations into account when hiring or promoting scholars or when reviewing their contributions for the purpose of effecting salary adjustments, awarding chairs, or distinguished professorships, etc. Citations, therefore, constitute an important property right in the largely non-market environment of higher education.

Posner (2000, p. 384) provides a major reason for citations, namely to establish priority among competing claims:

C.K. Rowley ( $\varangle)$

George Mason University, Fairfax, VA, USA

e-mail: crowley@gmu.edu 
In scientific and social scientific fields, with the partial exception of law, most citations are "priority" citations. Strictly, priority citations are a subset of information citations; the priority is in making an argument discovering an idea, or inventing a product or process. But whereas a writer will make information citations without prodding, simply in order to make his work more valuable to the reader, he will make priority citations (except to himself!) reluctantly, under the constraint of the anti-plagiarism norm.

Posner also suggests that citation behavior may well become "strategic", with authors citing themselves for the purpose, inter alia, of increasing their competing claims to originality, their citations counts and their reputations. However, Posner neglects to mention the further possibility that an intentional or unintentional failure by an author to cite prior contributions by others may deny the original authors their priority, and may unfairly tilt future citations away from the pioneering authors. This commentary specifically addresses and attempts to redress this latter situation with respect to relevant publications of Janet Landa and Avner Greif.

The commentary will establish that Avner Grief, by his curious citation practices, has failed to cite seminal papers by Janet Landa who pioneered in an important field of nonmarket decision-making - the economics of trust, which itself is part of the economics of identity — and that, by so doing, he now is inappropriately recognized among mainstream economists as the pioneer in the field of trust networks and informal enforcement of contracts.

To a considerable extent, the informal scholarly rules concerning citations are grounded on a trust relationship between members of the community of scholars that they will assiduously review the relevant scholarly literature for papers predating their own contributions, and that they will conscientiously cite all such prior contributions. This trust relationship has been clearly severed in this case. Ironically, the intellectual property right that Avner Greif has expropriated from Janet Landa by his failure to cite her published works concerns the role played by trust relationships as an informal mechanism for facilitating trade in the absence of formal trading markets.

\section{Janet Landa's original field research and doctoral dissertation}

Janet Landa laid the groundwork for her original insight in her doctoral dissertation (Landa 1978) through six months of arduous fieldwork, July through December 1969, studying the nature of the marketing of smallholders' rubber in Singapore and West Malaysia. Her study focused attention on the role played by various groups in the multi-ethnic society: Malay smallholders produced the rubber, Chinese middlemen linked these Malay producers with exporters who shipped the rubber to international markets. In the absence of a fully-fledged market economy, with a well-developed legal framework for contract enforcement, how was this Chinese group able to supply this important middleman function? Janet Landa's answer to this question would provide a non-trivial modification to standard Edgeworth and Walrasian theories of exchange.

To find the answer to her question, Janet Landa collected information by conducting detailed questionnaire surveys of a sample of Malay rubber-holders and Chinese rubber dealers, supplemented by in-depth interviews of important rubber dealers in Singapore and West Malaysia involved in this trade.

In her doctoral dissertation (Landa 1978) utilized the ethnographic data she gathered to demonstrate that the marketing of smallholders' rubber, through the various levels of 
the vertical marketing structure, was dominated by the Hokkien-Chinese middleman group with a tightly-knit structure, consisting of four major clans (the Tans, the Lees, the Ngs, and the Gans) originating mainly from the Chuanchow and Yunchaun districts in Fukien province. The Hokkien-Chinese ethnic group was the largest among the Chinese population in Singapore and West Malaysia, composed of five major dialect/ethnic groups: Hokkiens, Teochews, Cantonese, Hakka, and Hainanese.

She showed that, in the absence of a well-developed contract law for enforcing contracts, mutual trust and mutual aid formed the basis for the particularization of exchange relations along kinship and ethnic lines among these Chinese middlemen. She further showed that, because of this trust relationship within the Chinese middleman economy, transactions among middlemen were based on credit, whereas, because of the absence of a trust relationship, Chinese middlemen used cash transactions in their dealings with the indigenous Malay smallholders (Landa 1978, 1981).

Her fieldwork and subsequent data analysis revealed that Chinese middlemen were not just a random collection of Chinese traders. Rather they were linked together in complex networks of personalized or particularistic exchange relations to form an ethnically homogeneous middleman group (EHMG):

the real significance of the visible, surface structure of the EHMG lies in its underlying deep structure: the invisible code of ethics, embedded in the personalized exchange relations among the members of the EHMG, which function as constraints against breach of contract and hence facilitate exchange among Chinese middlemen. The EHMG thus reveals itself to be a low-cost club-like institutional arrangement, serving as an alternative to contract law and the vertically integrated firm, which emerged to economize on contract-enforcement and information costs in an environment where the legal infrastructure was not well developed. (Landa 1981, p. 350, italics added).

\section{Janet Landa's key publications on the trust relationship}

\subsection{A theory of the ethnically homogeneous middleman group}

This is Janet Landa's first, and most important paper on the economic analysis of trust and identity and was published in The Journal of Legal Studies (Landa 1981).

The 1981 paper presents a novel economic theory of the formation of the ethnically homogeneous middleman group derived from the field work evidence presented in her doctoral dissertation. Under conditions of contract uncertainty with positive transaction costs, she suggests, a rational trader will not trade with anonymous traders, but will equip himself with a "calculus of relations" for the discriminatory choice of potential trading partners with varying degrees of social distance. This allows the trader to rank all potential trading partners in the market according to a small number of categories, corresponding to different grades of traders, in a descending order of trustworthiness. She describes this grading system in terms of a von Thünen series of concentric circles with the best grade located at the center.

A cost-minimizing middleman, under conditions of contract uncertainty, will choose trading partners with shared and easily identifiable kinship and ethnic characteristics because the Confucian ethic of reciprocity is embedded in these close kinship/ethnic relations. Thus, a Hokkien-Chinese middleman, relying on easily identifiable kinship/ethnic markers as reputation signals, will trade more readily under conditions of contract uncertainty with 
kinsmen and fellow Hokkien-Chinese, substituting trust-relationships for reliance on cash transactions and formal contract law.

This trust-relationship will weaken successively as social distance increases: from near kinsmen from family, through distant kinsmen from extended family, through clansmen, through fellow villagers, through fellow Hokkien-Chinese, and through non-HokkienChinese. The trust relationship stops at the major ethnic boundary separating Chinese and non-Chinese, where the Confucian code of ethics no longer applies.

Janet Landa notes that her theory of the EHMG is applicable to other kinship-related and ethnically homogeneous traders, not just the Hokkien-Chinese in Singapore and West Malaysia. Notably, the ethnically homogeneous Italian Mafia group is a low-cost club for the effective enforcement of contracts in an extra-legal environment. Similar arguments hold with respect to such homogeneous traders as: "the East Indians in East Africa, the Syrians in West Africa, the Lebanese in North Africa, the Jews in Medieval Europe ${ }^{1}$ and the Medici merchant-bankers in fifteenth-century Florence" (Landa 1981, p. 361).

\subsection{The economics of symbols, clan names, and religion}

In this paper, also published in The Journal of Legal Studies, Carr and Landa (1983) extend the analysis to include other EHMGs, such as the East Indians in Africa, the Syrians in West Africa, the Lebanese in North Africa, and the Jews in Medieval Europe. Using Buchanan's (1965) club-theoretic approach, Carr and Landa analyze the economic benefits (lowered breach costs) and costs (enforcement and information transmission costs) of traders joining a homogeneous trading club. In addition, Carr and Landa analyze the optimal size of the ethnic trading club/network as the club expands to include increasing numbers of insiders, while excluding outsiders from the ethnic trade network.

Carr and Landa also explain seemingly puzzling customs and religious rituals, such as Jewish dietary laws, using signaling theory, to argue that these customs and religious rituals play important roles in lowering the costs of identifying trustworthy trading partners, as well as screening out outsiders by erecting costly barriers to entry.

\subsection{Personal versus impersonal trade: the size of trading groups and contract law}

In this paper, Cooter and Landa (1984) extend Carr and Landa (1983) formal club-theoretic model of the EHMG one step further by analyzing the relationship between the sizes of trading groups and the development of the law of contract. They view a trading group as an informal club-like arrangement for reducing breach of contract between members. They prove that membership of a club will decline if contracts with outsiders become more secure, i.e., when contract law becomes better developed. They summarize the model as follows:

We think of a trading group as a repository of trust which reduces the probability of breach on a contract between insiders. If the group expands, then members gain the advantage of a more extensive internal market. The advantage of a more extensive internal market is that it permits greater diversity of trade within the group. On the other hand, as the group expands, personal relations become attenuated. Personal relations enable the group to rely upon informal means of enforcement of contracts. If the group becomes quite large, formal methods of enforcement, which are more costly than informal methods, will have to be adopted to enforce contracts. (Cooter and Landa 1984, p. 16).

\footnotetext{
${ }^{1}$ I have italicized the fourth example to indicate by just how far in time Janet Landa anticipated the supposedly path-breaking work of Avner Greif.
} 
Cooter and Landa prove that the socially efficient trading group is smaller than the free entry trading group and larger than the monopoly trading group that maximizes benefits to its representative member. This explains why ethnic trading groups that monopolize trade by erecting costly entry barriers in the form of membership criteria meet with hostility, not only from excluded outsiders, but also from those who suffer from the monopoly prices. This hostility has provoked harsh responses, notably the racial riots against the Chinese by Malays in Malaysia in May 1969, the expulsion of Chinese middlemen from Indonesia during the 1960s and of East Indians from Uganda during the 1970s.

\subsection{Trust, ethnicity, and identity}

In 1994, Janet Landa integrated her previous writings on trust, ethnicity identity into a major book titled, Trust, Ethnicity, and Identity: Beyond the New Institutional Economics of Ethnic Trading Networks, Contract Law, and Gift-Exchange, published by The University of Michigan Press (Landa 1994). The book deals with the role of three major exchange institutions in achieving social order in different historical settings: contract law in developed capitalist economies, ethnic trading networks in developing economies, and gift-exchange in primitive stateless societies. The book draws heavily on concepts in the law and economics and public choice literature which form part of the new institutional economics.

The book develops a unifying theme: trust and identity matter for traders operating in an environment characterized by contract uncertainty, where the legal framework for the enforcement of contracts is not well developed. In such circumstances, trust, embedded in particularistic exchange relations such as kinship or ethnicity, serves as an informal means of protecting contracts (see Chap. 5, which is a reprint of Landa 1981, and Chap. 6 which is a reprint of Carr and Landa 1983). In primitive economies, recurring gift exchanges—such as the famous Kula Ring of the Trobriand Islands-serve to create trust among the tribes, facilitating exchange between the different tribes involved in Kula exchange (Landa 1983, reprinted as Chap. 7).

The book goes well beyond the transaction cost paradigm of the new institutional economics by incorporating crucial concepts from sociology and anthropology, such as social structure, social norms, social distance and culture, as well as concepts from evolutionary biology such as reciprocity and kin-related altruism

One might have thought, by the late 1980s, that Janet Landa's reputation as the pioneer of the economic analysis of trust was securely established, especially given that La Croix (1989) had published an article specifically evaluating her papers on the EHMG. As I shall explain, this has not come to pass. Instead, Avner Greif, by his curious citation practices, has attenuated Janet Landa's intellectual property right.

\section{Avner Greif's scholarly contributions to the trust-relationship literature}

Avner Greif is very much a 'Johnny-come-lately' to the trust relationship literature. Indeed, he was only just completing his baccalaureate degree in Economics and History of the Jewish People at Tel Aviv University when Janet Landa published her seminal 1981 paper.

He obtained his Doctorate in Economics at Northwestern University in 1988, one year before his first paper on the Maghirib traders entitled "Reputation and coalitions in medieval trade: evidence on the Maghribi traders" was published in the Journal of Economic History (Greif 1989). This was followed by his widely cited paper, published in the American Economic Review, "Contract enforceability and economic institutions in early trade: the Maghribi traders' coalition” (Greif 1993). 
These two papers are drawn from Avner Greif's 1988 doctoral dissertation. They are so similar that I shall treat them as a composite, indicative of Avner Greif's early work on Maghribi trading in medieval Europe. Greif focuses attention on the role played by the informal reputation and information system embedded in the "Maghribi trading coalition" that facilitated 11th-century trade in the Muslim Mediterranean under conditions of transactional insecurity (Greif 1989, 1993). The similarity between his analysis and that of Janet Landa is readily apparent, although Greif, unlike Landa, was obviously unable to ground his theory on the basis of ethnographic field-work research.

Greif $(1989,1993)$ utilizes an historical source found in Old Cairo known as the 'deposit place' (geniza). This source contains approximately 1000 contracts, price lists, traders' letters, accounts and other documents that reflect 11th-century trade in the Muslim Mediterranean (Greif 1993, p. 526). The documents were written in Hebrew characters by Jewish traders known as the Maghribi traders who operated mainly in the western basin of the Mediterranean. Greif conjectures that these documents contain a representative sample of the Maghribi traders' commercial correspondence (Greif 1993, p. 526).

Greif's papers are concerned with an institution that surmounted a commitment problem intrinsic in the relations between merchants and their overseas agents. In pre-modern trade, a merchant had to organize the supply of services for the handling of his goods overseas. He could either travel with his merchandise between trade centers or hire overseas agents to supply the service. The use of agents was efficient, saving travel time and allowing diversification of sales across trade centers. However, without supporting institutions, agency relations would not emerge because of the risk of opportunistic behavior and outright embezzlement. Yet, merchant-agent relations existed throughout the Maghribi trading networks.

Greif $(1989,1993)$ hypothesizes that a ‘coalition' governed agency relationships within the Maghribi trading system. Expectations, implicit contractual relations and a specific information-transmission mechanism constrained individual trader's opportunism. Jointly, these constraints supported a reputation mechanism that enabled the Maghribi to overcome the opportunism/commitment problem under conditions of contract uncertainty.

Greif $(1989,1993)$ was unable to test such hypotheses statistically. Instead, he utilized the historical documents to identify the nature of the opportunism/commitment problem, using this information to construct a relevant game-theoretical model. He used statements from the documents to identify the equilibrium strategies of the Maghribi traders. On this basis he extended the model to generate predictions about facts other than those assumed in the model. Finally, he confronted these predictions with the historical evidence.

On this basis, he concluded that agency relations among the Maghribis were governed by a 'coalition'. The coalition is defined as a group of traders whose member merchants are expected to hire only member agents whose behavior is governed by coalition rules. An informal information-transmission mechanism enables merchants to monitor agents and makes cheating known to all.

Greif's analysis is based less on hard data than on a careful interpretation of a set of ancient documents supplemented by game-theoretic modeling. Game theory is a useful tool for understanding revealed behavior. Yet it is far from fool-proof. There are many competing game theory formulations and, in many cases Nash [or strategic] equilibria, even when they exist, may not be unique.

It is not at all surprising, therefore, to learn that Greif's 1989 and 1993 papers are now under critical scrutiny following a challenge from Edwards and Ogilvie (2008, p. 1) who counter-claim that "Not a single empirical example adduced by Greif showed that a coalition actually existed" and that the Maghribi traders entered into business associations with 
non-Maghribi traders and used formal legal enforcement mechanisms to protect against opportunism among their agents. However, this controversy lies beyond the scope of my commentary.

\section{Greif's curious citation practices}

In his first (Greif 1989) paper, Avner Greif cites Janet Landa's unpublished 1978 doctoral thesis as well as her unpublished 1988 Hoover Institution Working Paper, circulated by the Hoover Institution at Stanford University-where Janet Landa had been appointed as a 1986-1987 National Fellow. Avner Greif joined Stanford University two years later, in 1989. Janet Landa's 1988 paper itself cites two of her already published papers (Landa 1981; Carr and Landa 1983). These published papers are not cited by Greif. Greif's (1989, p. 882) terse comment on this 1988 unpublished paper is as follows:

Interestingly, empirical evidence on exchange relations in ... South East Asia suggests that reputation and implicit contracts among members of "coalitions" still play an important role in helping businessmen overcome contractual problems.

In his influential 1993 paper, published in the American Economic Review (Greif 1993), Greif once again cites Landa's unpublished 1978 doctoral dissertation as well as her unpublished 1988 paper (Landa 1988). Again, he speaks tersely about her 1988 paper:

Similarly, culture may substitute for comprehensive contracts by specifying ex ante systematic rules of behavior (Greif 1993, pp. 542-543).

And this gets curiouser and curiouser: Even if Avner Greif was unaware of Janet Landa's publications on her theory of the ethnically homogeneous middleman group prior to 1994, he surely should have become acquainted with them in that year when the University of Michigan Press published her book (Landa 1994). This book brought together her previous publications on the topic, including the seminal articles (Landa 1981; Carr and Landa 1983) outlined in Sect. 3 above. In Chap. 5 of her book (Landa 1994, p. 114) made a slight change to her 1981 reprinted article by adding Greif's 1989 article to her references, thus placing her contribution into the wider developing literature of ethnic trading networks.

In 1995, Greif reviewed her book for the Canadian Journal of Economics (Greif 1995). His review is not at all unfavorable; but it completely fails to acknowledge Janet Landa's intellectual property right in the economic analysis of the ethnically homogeneous networks/groups. He recognizes that: '[s]even of nine chapters in the book are slightly revised versions of papers written by the author during the late 1970s and early 1980s' (Greif 1995, p. 1228). Greif notes that this explains why 'she does not take advantage of game theory in analyzing situations that are inherently strategic' (Greif 1995, p. 1228). He fails to mention, in this regard, however, that Janet Landa's prior field work made game theory largely redundant, since the strategic behavior that she describes is already fully identified.

Furthermore, Greif's comment about game theory could be used to downgrade unfairly the work of many innovative scholars whose breakthrough insights came before new techniques developed. For example, Coase's (1960) insight into the nature of social cost also came before game theory emerged as a useful economic tool. Should some Johnny-comelately scholar now appropriate the Coase theorem by giving his original insight a gametheoretic twist?

Greif recognizes Chap. 5 (reprint of Landa's 1981 paper) as the most important essay in the book: 'This is a well-articulated chapter, which perhaps constitutes the cornerstone of 
the book' (Greif 1995, p. 1230). He briefly outlines the findings of the essay, and provides minor criticisms concerning her over-emphasis on ethnicity as the basis for the emergence of efficient trading groups. His example of the emergence of urban gangs as non-ethnic, low-cost and effective substitutes (Greif 1995, p. 1230) is surely misplaced. Modern urban gangs in such major cities as New York, almost always emerge on the basis of ethnic identity among minority groups (for example, Irish, Italian, Hispanic, Asian and now Russian and Albanian) exploiting their close-knit status within larger diverse populations.

Greif's concludes by suggesting that Janet Landa's book 'has accomplished much, but it also shows that more is yet to be done' (Greif 1995, p. 1230). This conclusion makes no reference to the seminal nature of Janet Landa's early papers on the economic analysis of trust; nor does it attempt to place her work into its proper place in the history of economic thought. Greif makes no reference to his own work on the Maghribi traders' coalition, even though these works were clearly similar to and preceded by Janet Landa's theory of the ethnically homogeneous middleman group.

Yet, one would have thought that Avner Greif's knowledge of Janet Landa's scholarship as contained in his review of her book might have prodded his memory into citing her published papers in his subsequent writings on the economic analysis of trust. This was not to be; indeed quite the opposite in fact occurred.

In 2006, Greif published through Cambridge University Press his own major book drawing together scholarship on the trust relationship: Institutions and the Path to the Modern Economy: Lessons from Medieval Trade. Listed among the voluminous references to this 500-page tome are just the two unpublished works by Janet Landa (Landa 1978, 1988) which I mentioned earlier. A page-by-page scrutiny of the book itself indicates that even these two works are not referred to in its body. Janet Landa's name and publications are absent from Greif's (2006) text.

\section{Consequences}

The Journal of Legal Studies published Janet Landa's first and most important paper on the economics of the ethnically homogeneous middleman group in June 1981 (Landa 1981). In June 2008, her 1981 paper was ranked as the third most highly cited paper in the history of the JLS, itself a top-ten ranked economics journal. ${ }^{2}$ In most circumstances, this level of citation would guarantee an author a lasting reputation for effective innovation. For Janet Landa the situation is currently more problematic, as a direct consequence of Avner Greif's curious citation practices.

Over the period 1989 to 1997 , Avner Grief published some thirteen scholarly papers on trust relationships in medieval European trading. Typically, in each paper he cited a large number of well-known economists, many of whom worked in the field of the new institutional economics. In return, these scholars reciprocated readily, copiously citing his contributions. This situation intensified in 1998 when Greif was awarded a prestigious MacArthur Foundation Fellowship (colloquially referred to as 'a genius grant') paid out over a period of five years in the total sum of $\$ 500,000$.

Now famous, with a great number of citations, Avner Greif continued to publish on trust relationship issues, always somehow overlooking Janet Landa's publications when compiling his citation lists. Later-arriving mainstream scholars, perhaps themselves unwilling to

\footnotetext{
${ }^{2}$ See the University of Chicago (http://www.journals.uchicago.edu/toc/jls/current).
} 
expend time on researching the early literature, also bypassed Janet Landa's scholarship and cited Avner Greif as the pioneer in the field. The following is a small sample of many mainstream economists whose papers/books on the economic analysis of trust omit any reference to Janet Landa's papers: Iannaccone (1992), perhaps understandably, since he was writing on the economics of religion, McMillan and Woodruff (1999), Akerlof and Kranton (2000), Rauch (2001), Rauch and Trindade (2002), Khalil (2003) 800 page book on Trust, Dixit (2003, 2004, 2009), Bowles and Gintis (2004) and MacLeod (2007).

Of these authors, the following are especially ironic/ and or egregious: In Akerlof and Kranton (2000) paper on "Economics and Identity", while footnoting (Landa 1994) book, Trust, Etnicity, and Identity, the authors actually claim that their paper introduces identity into economics (italics supplied). Similarly, Rauch and Trindade (2002) while writing about Chinese networks in international trade, cite Greif's works on Jewish merchant networks while ignoring Janet Landa's earlier works on Chinese trading networks. Dixit, in his 2003 paper discusses, without any reference to Janet Landa's work, how traders separated by geographic and social space, enforce contracts when the legal framework is ineffective. The central theme of his 2004 book, again without reference to Janet Landa's work, concerns how property rights can be protected and contracts enforced in countries where the law is ineffective. Bowles and Gintis (2004) paper, "Persistent parochialism: Trust and exclusion in ethnic networks" contains key ideas from Janet Landa's three published papers on ethnic trading networks, written in the early 1980s (Landa 1981; Carr and Landa 1983; Cooter and Landa 1984) without any reference to her publications. ${ }^{3}$

In any event, although Janet Landa continues to be widely cited in the law and economics literature - and on occasion in the sociology literature (see Tilly 2005) — and continues to extend her theory of the ethnically homogeneous middleman group into new disciplinary areas like evolutionary biology (Landa 2008), her writings on the economic analysis of trust and identity have received no citations from mainstream economists since Avner Greif achieved fame and rapid academic promotion for his work on the Maghribi traders.

\section{Conclusions}

In the July 2007 issue of Public Choice, Robert D. Tollison criticizes scholars of the new political economy research program-notably Persson and Tabellini (2003) and Acemoglu (2005) — for their failure to cite the preceding scholarship of the founding fathers of public choice-notably Buchanan and Tullock (1962), Brennan and Buchanan (1980), and Buchanan (1986) — in an attempt to replace old wine with new wine (Tollison 2007, p. 4). Tollison acknowledges the important contributions of these well-known Johnny-come-lately scholars. However he concludes with a timely admonition: 'As we go forward, however, I hope we shall not forget Alfred Marshall's dictum that we stand on the shoulders of giants' (Tollison 2007, p. 4).

I conclude this commentary with the same admonition, most especially to Avner Greif, but also to those above-mentioned scholars who have picked up only on Greif's incomplete citation lists. Because of Avner Greif's curious citation practices, Janet Landa has come to

\footnotetext{
${ }^{3}$ Hodgson (2006, p. 170), in his review of Bowles (2004), comments as follows: "Bowles persuasively emphasizes the frequent importance of communities, clans or ethnic ties in the enforcement of contracts, citing his recent work with Herbert Gintis, and the preceding works of Elinor Ostrom and William Ouchi, but not the pioneering and highly pertinent studies of Janet Landa, to which the later work of Bowles and Gintis in this area bears some similarity."
} 
grief. Please henceforth have the good grace to restore her priority by citing her published papers on the EHMG. Janet Landa earned her intellectual property right by hard-work and great insight. She deserves to be acknowledged as the pioneer in the economics of trust and the economics of identity, in particular for her work on the ethnically homogeneous middleman group/trust networks.

\section{References}

Acemoglu, D. (2005). Constitutions, politics, and economics. Journal of Economic Literature, 43, 10251048.

Akerlof, G. A., \& Kranton, R. E. (2000). Economics and identity. Quarterly Journal of Economics, 115(3), $715-753$.

Bowles, S. (2004). Microeconomics: behavior, institutions and evolution. Princeton: Princeton University Press.

Bowles, S., \& Gintis, H. (2004). Persistent parochialism: trust and exclusion in ethnic networks. Journal of Economic Behavior and Organization, 55, 1-23.

Brennan, H. G., \& Buchanan, J. M. (1980). The power to tax: analytical foundations of a fiscal constitution. Cambridge: Cambridge University Press.

Buchanan, J. M. (1965). An economic theory of clubs. Economica, 32, 1-14.

Buchanan, J. M. (1986). The constitution of economic policy. In Les prix Nobel. Stockholm: Almqvis and Wiksell.

Buchanan, J. M., \& Tullock, G. (1962). The calculus of consent: logical foundations of constitutional democracy. Ann Arbor: University of Michigan Press.

Carr, J., \& Landa, J. T. (1983). The economics of symbols, clan names and religion. Journal of Legal Studies, $13,135-156$.

Coase, R. H. (1960). The problem of social cost. Journal of Law and Economics, 3, 1-44.

Cooter, R., \& Landa, J. T. (1984). Personal versus impersonal trade: the size of trading groups and contract law. International Review of Law and Economics, 4, 15-22.

Dixit, A. K. (2003). Trade expansion and contract enforcement. Journal of Political Economy, 111(6), 12931317.

Dixit, A. K. (2004). Lawlessness and economics: alternative modes of governance. Princeton: Princeton University Press.

Dixit, A. K. (2009). Governance institutions and economic activity. American Economic Review, 99(1), 5-24.

Edwards, J., \& Ogilvie, S. (2008). Contract enforcement, institutions and social capital: the Maghribi traders reappraised (Working Paper). University of Cambridge, Department of Economics.

Greif, A. (1989). Reputation and coalitions in medieval trade: evidence on the Maghribi traders. Journal of Economic History, 49(4), 857-882.

Greif, A. (1993). Contract enforceability and economic institutions in early trade: the Maghribi traders' coalition. American Economic Review, 83(3), 525-548.

Greif, A. (1995). Review of "Trust, ethnicity, and identity" by Janet T. Landa. Canadian Journal of Economics, 28(4), 1228-1230.

Greif, A. (2006). Institutions and the path to the modern economy: lessons from medieval trade. Cambridge: Cambridge University Press.

Hodgson, G. M. (2006). Review of "Microeconomics: behavior, institutions, and evolution" by S. Bowles. Economics and Philosophy, 22, 166-171.

Iannaccone, L. R. (1992). Sacrifice and stigma: reducing free-riding in cults, communes and other collectives. Journal of Political Economy, 100, 271-311.

Khalil, E. E. (Ed.). (2003). Trust. Cheltenham: Edward Elgar.

La Croix, S. J. (1989). Homogeneous middleman groups: what determines the homogeneity? Journal of Law, Economics, and Organization, 5, 211-222.

Landa, J. T. (1978). The economics of the ethnically homogeneous middleman group: a property rights-public choice approach. Ph.D. Dissertation, Blacksburg: Virginia Polytechnic University and State University.

Landa, J. T. (1981). A theory of the ethnically homogeneous middleman group: an institutional alternative to contract law. The Journal of Legal Studies, 10, 349-362.

Landa, J. T. (1983). The enigma of the Kula Ring: Gift exchanges and primitive law and order. International Review of Law and Economics, 3, 137-160.

Landa, J. T. (1988). A theory of the ethnically homogeneous middleman group: beyond markets and hierarchies (Working Paper). Hoover Institution, Stanford University. 
Landa, J. T. (1994). Trust, ethnicity, and identity: the new institutional economics of ethnic trading networks, contract law, and gift-exchange. Ann Arbor: University of Michigan Press.

Landa, J. T. (2008). The bioeconomics of homogeneous middleman groups as adaptive units: theory and empirical evidence viewed from a group selection framework. Journal of Bioeconomics, 10(1), 259278.

MacLeod, W. B. (2007). Reputation, relationships and contract enforcement. Journal of Economic Literature, $45,595-628$.

McMillan, J., \& Woodruff, C. (1999). Interfirm relationships and informal credit in Vietnam. Quarterly Journal of Economics, 114(4), 1285-1320.

Persson, T., \& Tabellini, G. (2003). The economic effects of constitutions. Cambridge: MIT Press.

Posner, R. A. (2000). An economic analysis of the use of citations in the law. American Law and Economics Review, 2(2), 381-406.

Rauch, J. E. (2001). Business and social networks in international trade. Journal of Economic Literature, 39 , 1177-1203.

Rauch, J. E., \& Trindade, V. (2002). Ethnic Chinese networks in international trade. The Review of Economics and Statistics, 84(1), 116-130.

Tilly, C. (2005). Trust and rule. Cambridge: Cambridge University Press.

Tollison, R. D. (2007). Old wine, new wine. Public Choice, 132(1-2), 3-5. 